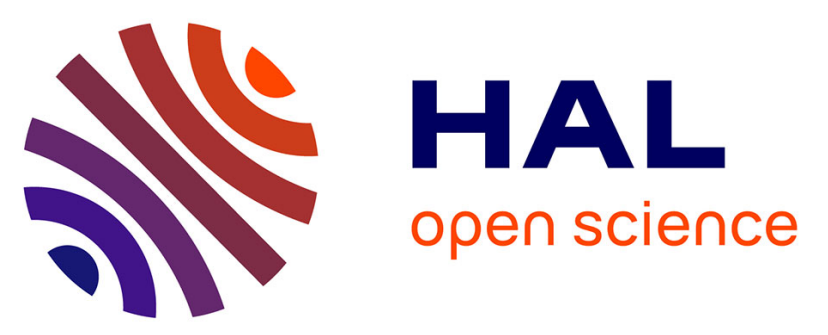

\title{
Mangrove sediment carbon stocks along an elevation gradient : influence of the late Holocene marine regression (New Caledonia)
}

Adrien Jacotot, Cyril Marchand, Brad E. Rosenheim, Eugene Domack, Michel Allenbach

\section{To cite this version:}

Adrien Jacotot, Cyril Marchand, Brad E. Rosenheim, Eugene Domack, Michel Allenbach. Mangrove sediment carbon stocks along an elevation gradient: influence of the late Holocene marine regression (New Caledonia). Marine Geology, 2018, 404, pp.60-70. 10.1016/j.margeo.2018.07.005 . hal-01919481

\section{HAL Id: hal-01919481 \\ https: / hal.sorbonne-universite.fr/hal-01919481}

Submitted on 12 Nov 2018

HAL is a multi-disciplinary open access archive for the deposit and dissemination of scientific research documents, whether they are published or not. The documents may come from teaching and research institutions in France or abroad, or from public or private research centers.
L'archive ouverte pluridisciplinaire HAL, est destinée au dépôt et à la diffusion de documents scientifiques de niveau recherche, publiés ou non, émanant des établissements d'enseignement et de recherche français ou étrangers, des laboratoires publics ou privés. 


\title{
Mangrove sediment carbon stocks along an elevation gradient: Influence of the late Holocene marine regression (New Caledonia)
}

\author{
Adrien Jacotot ${ }^{\mathrm{a}, \mathrm{b}, *}$, Cyril Marchand ${ }^{\mathrm{a}}$, Brad E. Rosenheim ${ }^{\mathrm{c}, \mathrm{d}}$, Eugene W. Domack ${ }^{\mathrm{d}, \mathrm{e}}$, \\ Michel Allenbach ${ }^{\mathrm{b}}$ \\ a IMPMC, Institut de Recherche pour le Développement (IRD), UPMC, CNRS, MNHN, Noumea, New Caledonia, France \\ ${ }^{\mathrm{b}}$ Université de la Nouvelle-Calédonie, ISEA, EA 7484, BPR4, 98851 Noumea, New Caledonia, France \\ ${ }^{c}$ Department of Earth and Environmental Sciences, Tulane University, New Orleans, LA, USA \\ ${ }^{\mathrm{d}}$ College of Marine Science, University of South Florida, St. Petersburg, FL, USA \\ ${ }^{\mathrm{e}}$ Nelson Institute of Environmental Studies, University of Wisconsin, Madison, WI, USA
}

Keywords:

Blue carbon

Carbon isotopes

Carbon sequestration

Coastal wetlands

Sea-level change

Semi-arid mangrove forest

\begin{abstract}
A B S T R A C T
Among blue carbon ecosystems, mangroves are very efficient in storing carbon in their sediments over decadal to millennial time scales. However, this ability varies with numerous parameters, including climate and sea-level variations. In New Caledonia, mangrove ecosystems develop in semi-arid conditions with a typical zonation: Rhizophora spp. colonize the seaward side of the intertidal area, while Avicennia marina develops at higher elevations, just below the salt-flat. Within this context, we determined both the quantity (organic carbon content and carbon stocks) and the characteristics (carbon over nitrogen ratios $(\mathrm{C} / \mathrm{N})$, stable carbon and nitrogen isotopes, radiocarbon age) of the organic matter stored beneath each mangrove stands. Carbon stocks were determined down to different limits with depth: approximate extension of the root systems, one-meter depth, and the hard substrate. Within the extension of the root systems, the sediment carbon stock was lower than $100 \mathrm{MgC} \mathrm{ha}^{-1}$ regardless of the mangrove species. This low value resulted directly from the dry climate that limits mangrove productivity. At depth beneath every zone, a buried layer enriched in mangrove-derived organic matter, with $\mathrm{C} / \mathrm{N}$ values around 40 and $\delta^{13} \mathrm{C}$ values around $-26 \%$ was observed. This layer likely resulted from a sea-level high stand during the late Holocene that allowed a long period of stability of the mangrove, slowly accumulating organic matter within the sediment. In this buried layer, the carbon stock was higher than in the upper sediment and reached up to 665,255 and $300 \mathrm{MgC} \mathrm{ha}^{-1}$ in the salt-flat zone, the A. marina stand and the $R$. spp. stand, respectively. The highest stock, determined beneath the salt-flat, was suggested to be related to a period of sea-level stability that lasted $\sim 3000$ years, whereas beneath the other zones, which are at lower elevations, mangrove colonization was more recent and the sea-level was continuously decreasing till recently. Sealevel variations, and, specifically current sea-level rise, may strongly influence mangrove development due to their migration along the tidal elevation gradient to maintain the biotic conditions needed for their development.
\end{abstract}

\section{Introduction}

Mangroves are considered as major ecosystems in the carbon cycle along tropical and subtropical coastlines, being among the most efficient blue carbon sinks (Mcleod et al., 2011). This specificity results from a combination of different parameters including i) their high

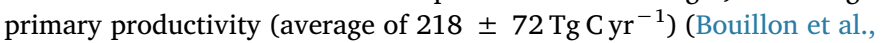
2008), ii) the anoxic character of their sediment resulting from waterlogging and limiting organic matter (OM) decay processes (Kristensen et al., 2008), and thus iii) their high belowground storage capacity, with up to $15 \%$ of mangrove productivity being buried in mangrove sediments (Breithaupt et al., 2012). As a result, potentially up to $98 \%$ of their carbon content is stored in their substrate (Donato et al., 2011; Murdiyarso et al., 2015), and organic matter can accumulate over several meters depth on decades to millennial time scales (Dittmar and Lara, 2001; Lallier-Vergès et al., 2008; Twilley et al., 1992). This contrasts with other highly productive ecosystems in which the labile OM produced can be rapidly mineralized. In addition, the amount of carbon stored in mangrove sediments can be highly variable. On a local scale, they depend notably on tree species, sediment salinity, nutrient availability, and, thus, on the forest's position in the tidal zone (Kauffman et al., 2011; Adame et al., 2013; Mizanur Rahman et al., 2015; Wang

\footnotetext{
* Corresponding author at: Institut de Recherche pour le Développement, BPA5, 98848 Nouméa, New Caledonia, France.

E-mail address: adrien.jacotot@protonmail.com (A. Jacotot).
} 
et al., 2013). On a global scale, climatic conditions have been found to be important drivers controlling mangrove sediment carbon stocks, and a strong relationship between the latitudinal position of the mangrove and the organic carbon stored in the sediment can be established such that mangrove productivity is higher at low latitudes (Kristensen et al., 2008; Sanders et al., 2010; Alongi, 2012). Yet, most studies have been conducted on tropical and subtropical mangroves, and more data from temperate and arid mangroves are needed to ascertain the global mangrove carbon budget (Alongi, 2012; Sanders et al., 2016).

Integration depth is a major challenge when assessing carbon stocks in mangrove ecosystems and should be carefully taken into consideration (Lunstrum and Chen, 2014; Marchand, 2017). Determining the depth reached by the organic matter produced by the above forest is crucial if the objective is to assess the recent carbon stock (Ha et al., 2017; Marchand, 2017). Conversely, if the objective is to determine the total carbon stock of the ecosystem, the entire sediment profile, down to a hard substrate, should be sampled. However, mangrove ecosystems can migrate landward or seaward as sea-level rises or falls (Gilman et al., 2008), and, as a result, integrating the whole sediment profile results in adding the stock of different mangrove forests that developed at different sea-level.

Many studies were recently interested in the effects of Holocene sealevel variations on the evolution of mangrove ecosystems (e.g. Behling and da Costa, 2001; Ellison, 2008; França et al., 2016, 2013; Hait and Behling, 2009; Horton et al., 2005; Li et al., 2012; Monacci et al., 2011, 2009; Parkinson et al., 1994; Punwong et al., 2013; Woodroffe, 1981). Some of them were interested in the Pacific region (e.g. Engelhart et al., 2007; Fujimoto et al., 1996; Joo-Chang et al., 2015; Yulianto et al., 2004), and only a handful focused on New Caledonia (Cabioch et al., 2008; Wirrmann et al., 2011). However, studies reporting specific effects of sea-level variations on mangrove sediment carbon stocks are rare. For example, Ezcurra et al. (2016) reports that past sea-level rise allowed accumulation of large amount of organic matter due to the vertical accretion of the ecosystem to keep pace with sea-level rise.

In New Caledonia, mangrove forests cover over 35,000 ha, fringing on about $80 \%$ and $15 \%$ along the western and the eastern coastline of the island, respectively (Marchand et al., 2006). These forests exhibit a zonation of the vegetated species that develop in successive belts parallels to the coastline. Previous studies (Marchand et al., 2012, 2011a) suggested that the main factor controlling the distribution of mangrove species in New Caledonia was sediment salinity, which in turn was controlled by interactions between the duration of tidal inundations, freshwater inputs from rainfall and water streams and by soil elevation. Consequently, the upper sediment layers within the mangrove demonstrate gradients in water, salinity, and organic carbon contents, from the landward side to the seaward side (Deborde et al., 2015).

With such considerations of gradient, the main objectives of our study were: i) to determine the sediment carbon stocks along the intertidal zone, taking into account the forest developing above, ii) to determine the sediment carbon stocks down to the bedrock, and iii) to identify the possible influence of sea-level variations on sediment carbon stocks. We hypothesized that carbon stocks will decrease from the sea side to the land side as a result of lower forest productivity in the upper intertidal zone.

\section{Regional settings}

The study was conducted in New Caledonia, a French overseas archipelago located in the South Pacific, in the Melanesia sub region $\left(21^{\circ} 21^{\prime} \mathrm{S}, 165^{\circ} 27^{\prime} \mathrm{E}\right)$. The archipelago sheltered 35,100 ha of mangroves, composed of 24 different species (Marchand et al., 2006). The mangrove ecotone exhibits a zonation of the vegetated species, which includes: (i) a back-side salt-flat, a highly saline zone, only submerged during high spring tides, and sometimes covered by a halophile herb, Sarcocornia quinqueflora; (ii) a second, downstream stand of vegetation, occupied by Avicennia marina; (iii) finally, the seaward edge is occupied by Rhizophora spp., mainly $R$. stylosa, $R$. samoensis, and $R$. selala, and is submerged at each tide.

New Caledonia is subject to a tropical climate, classified "Am" following Köppen and Geiger classification. However, the west coast of the island and specifically the region of La Foa is subject to a drier climate, of "Aw" type. It is strongly influenced by the variation of the intertropical convergence zone (ITCZ) that defines two contrasting seasons: a dry season from May to September, and a warm cyclonic season from November to April. In addition, the El Niño Southern Oscillation (ENSO) induces a drier climate during El Niño phases by reducing the precipitations and increasing the trade winds frequency and strength. Mean annual rainfall and air temperature in La Foa for the last 4 years were $1040 \mathrm{~mm}$ and $22.8^{\circ} \mathrm{C}$, respectively (data from meteofrance.com).

Holocene sea-level changes in New Caledonia were examined through peat and reef cores, along with fossils corals, oysters samples and shorelines markers as for example mangroves species extension (Baltzer, 1982, 1970; Cabioch et al., 1989; Lecolle and Cabioch, 1988; Yamano et al., 2014). The latest researches stated that the postglacial Pleistocene/Holocene marine transgression was followed by a sea-level high stand from 6500 until 2800 cal yr. During this high stand, the sea level was $\sim 1.1 \mathrm{~m}$ higher than actual. After $2800 \mathrm{cal}$ yr, the sea-level fall until the current level (Yamano et al., 2014).

\section{Material and methods}

\subsection{Field work and sampling}

Field work was performed in the Amboa Swamp (Fig. 1a, b and c), which is in the upstream part of the estuarine mangrove forest of La Foa, on the west coast of the main island of the archipelago (Fig. 1a and b). This mangrove forest, part of the UNESCO World Heritage since 2008 , is one of the most extensive on the archipelago covering > 1000 ha and presents the typical zonation of New Caledonian mangroves (Figs. 1c and 2).

Three sediment cores per site were collected using an Eijkelkamp gouge auger (1-meter-long, $8 \mathrm{~cm}$ in diameter) (Fig. 1c). For each site, two of the three sediment cores were collected down to $50 \mathrm{~cm}$ in depth in order to determine organic matter characteristics and quantity related to the development of the above forest. The third core was collected down to the first hard substrate to evaluate the carbon stock of the mangrove (Lunstrum and Chen, 2014) and to determine the ecosystem evolution induced by past sea-level variations. These three long cores were named: LF1 in the salt-flat, LF2 in the Avicennia marina stand, and LF3 in the Rhizophora spp. stand (Fig. 1c). Taking into account the relatively low variability between the triplicate cores for the upper $50 \mathrm{~cm}$ in each stand (Table 4), we feel confident that our results below this depth are representative of the system, even if we were able to collect just one long core per zone due to logistical difficulties.

To determine the vegetation characteristics, three areas of $10 \mathrm{~m} \times 10 \mathrm{~m}$ were delimited in both A. marina and $R$. stylosa stands, close to the core positions. The number of trees were counted, and their respective height were measured. Additionally, twenty fresh and mature leaves were randomly sampled on trees surrounding the core positions in order to measure their $\delta^{13} \mathrm{C}$ and $\delta^{15} \mathrm{~N}$ values and their $\mathrm{C} / \mathrm{N}$ ratios. Similarly, fresh wood and roots were sampled.

Altitudinal heights, reported to the mean sea-level (MSL), of the three cores, and the vertical limits of the vegetation along the intertidal zone were obtained using a differential GPS (Trimble R4 GNSS). Altitudinal position of the three sites was recorded in triplicate. GPS processing was made in real-time, with a reference point obtained from the DITTT (Direction of Infrastructures, Topography and Land Transport) agency of New Caledonia. Horizontal and vertical precision were centimetric. 


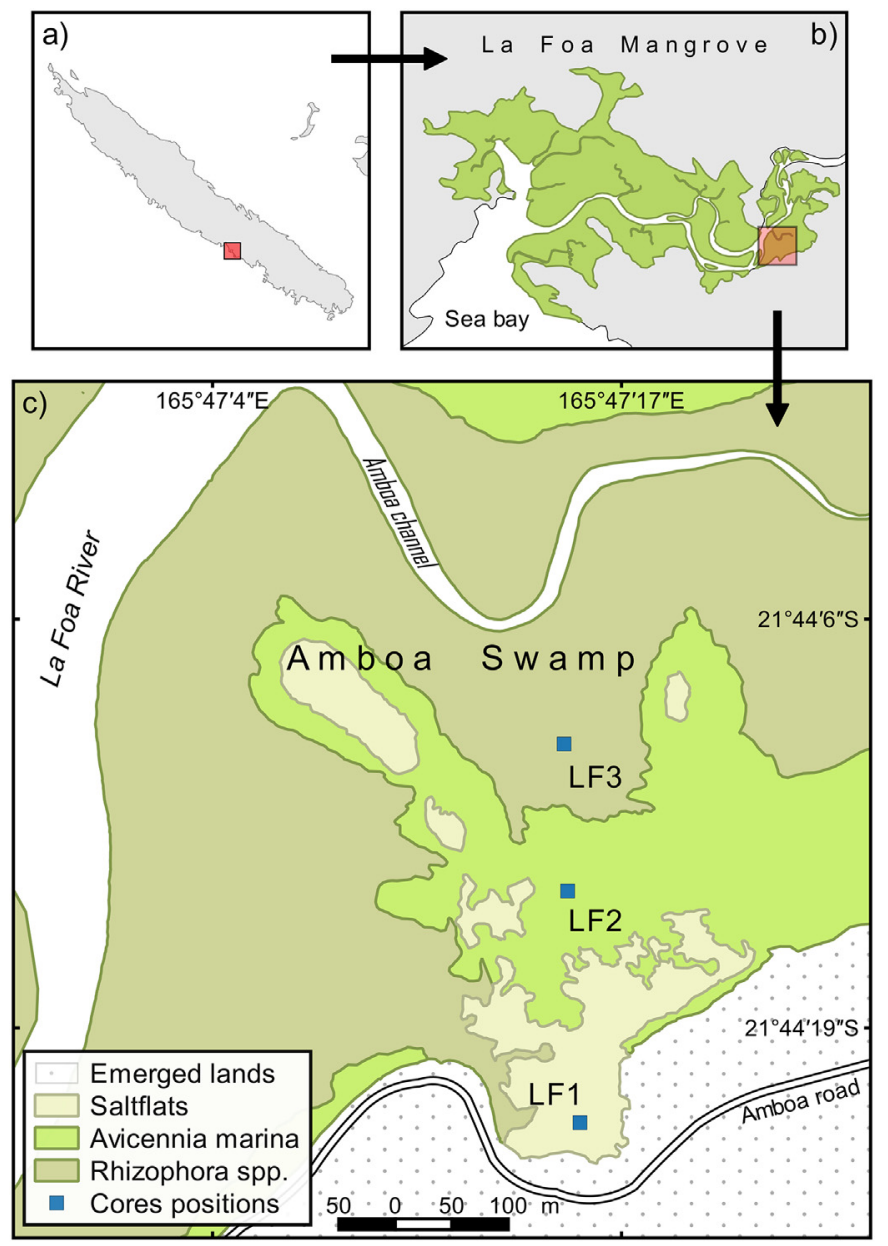

Fig. 1. (a) Location of the Amboa Mangrove Swamp in New Caledonia, and (b) in the La Foa estuary system. (c) Representation of the species zonation, and cores positions.

\subsection{Radiocarbon dating}

Samples of wood debris were manually selected from the bottom of each core for radiocarbon dating. Two additional samples were taken, one in the interval $65-70 \mathrm{~cm}$ depth in the salt-flat, and one in the interval $30-35 \mathrm{~cm}$ depth in the Avicennia stand, as these intervals presented clear stratigraphic evolution along these two cores. All wood samples were acid-base-acid treated and combusted at $900{ }^{\circ} \mathrm{C}$ over copper oxide in vacuo at the College of Marine Science, University of South Florida. Samples of $\mathrm{CO}_{2}$ gas were subsequently submitted for radiocarbon analysis at the National Ocean Sciences Accelerator Mass Spectrometry Facility (NOSAMS) at Woods Hole Oceanographic Institution (WHOI). Temporal accuracy of radiocarbon analysis was < 25 yrs. Calibration of radiocarbon ages to calendar ages was done using OxCal version 4.3 (Bronk Ramsey, 2009) with the SHCal13 curve (Hogg et al., 2013).

\subsection{TOC, TIC, and stable isotopes $\left(\delta^{13} C\right.$ and $\left.\delta^{15} N\right)$ analysis}

Each core was split into $5 \mathrm{~cm}$ intervals directly after collection, and then a subsample of a known volume was collected from each interval. Subsamples were freeze-dried until a constant weight was achieved. The dried bulk density (DBD) of each sample was obtained by dividing the dry mass by the fresh volume. Leaves, wood and root samples were rinsed with dezionized water to remove sediment and salt, and then dried at $55^{\circ} \mathrm{C}$ for $72 \mathrm{~h}$.

Total organic carbon (TOC) and total inorganic carbon (TIC) contents were determined using a Total Organic Carbon Analyzer coupled to a SSM-5000A Solid Sample Module (TOC-LCPH-SSM500A, Shimadzu Corporation, Japan). The analytical precision was checked using glucose standard (Sigma Aldrich) and was $<1 \%$ and $1.5 \%$ for TOC and TIC, respectively. Stable isotopes $\delta^{13} \mathrm{C}$ and $\delta^{15} \mathrm{~N}$ were analyzed using an elemental analyzer coupled to an isotope ratio mass spectrometer (Integra2, Sercon, UK). Stable isotopes values $\left(\delta^{13} \mathrm{C}\right.$ and $\left.\delta^{15} \mathrm{~N}\right)$ are reported in per mille (\%) deviations from Pee Dee Belemnite (PDB) for $\delta^{13} \mathrm{C}$, and from atmospheric nitrogen for $\delta^{15} \mathrm{~N}$. All the analyses were performed at the French Institute for the Sustainable Development (IRD) of Noumea, New Caledonia. The analytical precision was checked using IAEA-600 caffeine standard (IAEA Nucleus), and was $0.3 \%$ for C and $0.15 \%$ for $\mathrm{N}$. Carbon and nitrogen stable isotopes, in combination

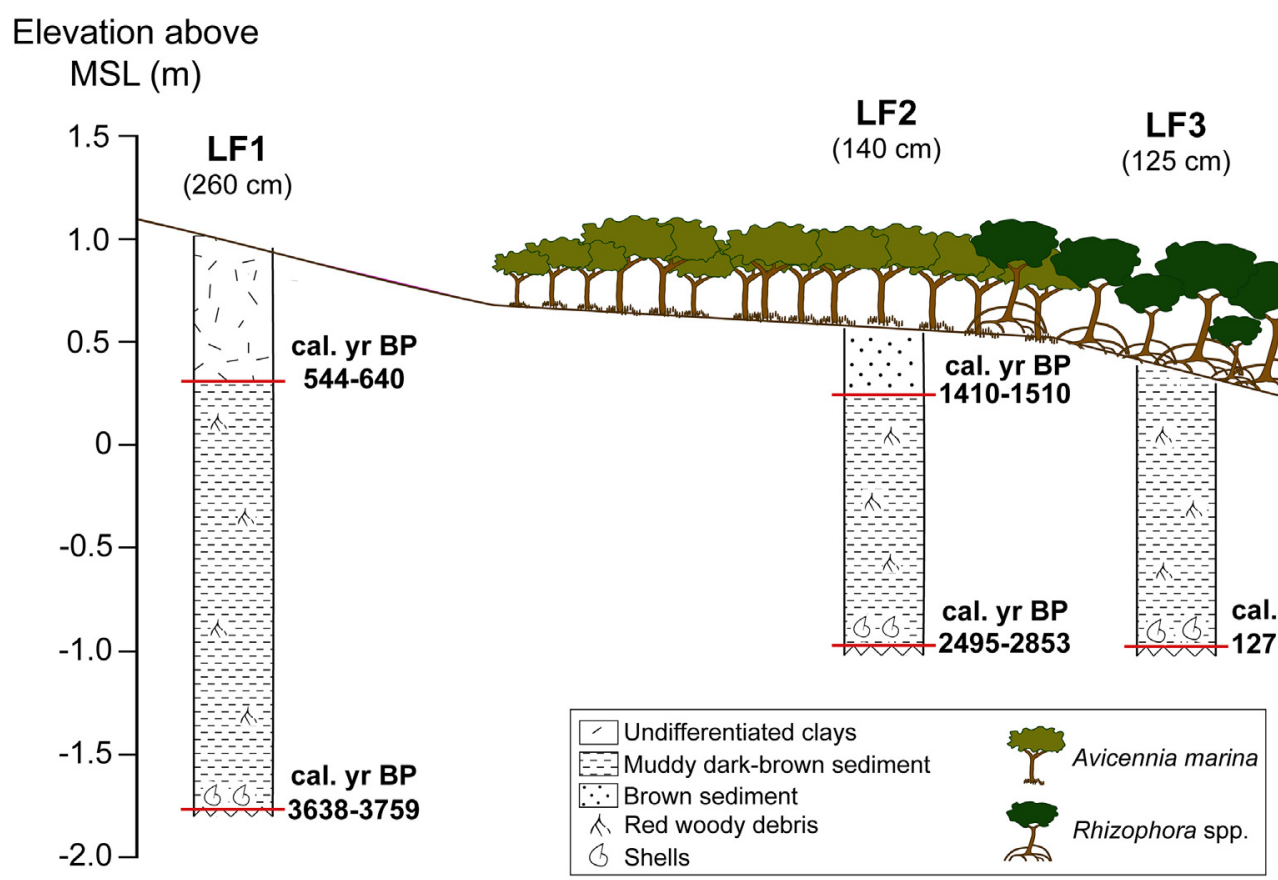

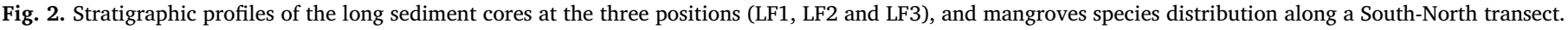
MSL: Mean Sea-level. Radiocarbon ages are reported as calibrated ages, with a $95.4 \%$ confidence interval. 
with $\mathrm{C} / \mathrm{N}$ ratios, are widely used geochemical tools to study organic matter dynamic in natural environments, as they allow both the identification of the OM sources and also diagenetic processes (Freudenthal et al., 2001; Matson and Brinson, 1990; Thornton and McManus, 1994; Voß and Struck, 1997).

To evaluate the depth reached by the organic matter derived from the above forest, we used a combination of parameters: (i) the sedimentological aspects of the cores (Fig. 2), and (ii) the vertical distribution of $\mathrm{C} / \mathrm{N}$ ratios and stable isotopes $\delta^{13} \mathrm{C}$ and $\delta^{15} \mathrm{~N}$ (Table 4).

\subsection{Carbon stocks calculation}

The carbon density (CD) of each sample was calculated using DBD and TOC values. Then, the sediment carbon stock in the different sediment layers was calculated using the following equation (Kauffman and Donato, 2012):

Sediment Carbon Stock $\left(\mathrm{MgC} \mathrm{ha}{ }^{-1}\right)=\operatorname{DBD}\left(\mathrm{g} \mathrm{cm}^{-3}\right) * \mathrm{TOC}(\%)$

*depth interval $(\mathrm{cm})$

\subsection{Statistical analysis}

Normality and equality of variance were analyzed using Shapiro and Fisher test, respectively. Following results, either a Student's $t$-test or a Mann-Whitney test was applied to investigate the significant differences $(\mathrm{P}<0.05)$ in $\mathrm{C} / \mathrm{N}$ ratios, $\delta^{13} \mathrm{C}, \delta^{15} \mathrm{~N}$ between the fresh tissues of both mangrove species. Similar analyzes were performed for significant differences in TOC, DBD and CD between the upper and bottom layers in each cores. In addition, a Multivariate Analysis of Variance (MANOVA) with $\delta^{13} \mathrm{C}, \delta^{15} \mathrm{~N}$ and $\mathrm{C} / \mathrm{N}$ as variables was applied to evaluate the significant differences between the two different layers observed in the three cores. To evaluate the significant differences between the bottom layers of the three mangrove stands in TOC, DBD and $\mathrm{CD}$ a one way analysis of variance (ANOVA) was performed after having tested normality and equality of variance using Shapiro and Levenne tests, respectively. All statistical analysis were performed under R software version 3.3.1 (R Development Core Team, Vienna, 2008).

\section{Results}

\subsection{Elevation and vegetation characteristics of the stands}

The salt-flat extended in the upper position of the intertidal zone, from 0.66 to $1.12 \mathrm{~m}$ above MSL, and was totally denuded. The A. marina stand developed at lower elevation, from 0.52 to $0.69 \mathrm{~m}$ above MSL. It was the densest vegetated stand, with $7167 \pm 815$ trees per hectare. The $R$. spp. stand was twice less dense, with $3667 \pm 1172$ trees per hectare, and developed in the lowest part of the intertidal zone, from -0.24 to $0.57 \mathrm{~m}$ above MSL. However, $R$. spp. trees were taller than $A$. marina trees with a mean height of $263 \pm 42 \mathrm{~cm}$ in comparison to $79 \pm 55 \mathrm{~cm}$ for $A$. marina trees (Table 1). Stations LF1 in the salt-flat, LF2 in the A. marina stand, and LF3 in the R. stylosa stand were situated at an elevation of $0.80 \pm 0.01,0.65 \pm 0.02$ and $0.59 \pm 0.01 \mathrm{~m}$ above MSL, respectively.

The mean $\mathrm{C} / \mathrm{N}$ ratios of the fresh mangrove tissues (leaves, wood and roots) were significantly higher for Rhizophora (94.85 \pm 46.05) than for Avicennia $(41.16 \pm 14.63)$ after a Mann-Whitney test $(\mathrm{U}=74.7 ; \mathrm{P}<0.001)$. Conversely, $\delta^{13} \mathrm{C}$ values were significantly higher (Student's $t$-test, $\mathrm{t}(16)=3.309, \mathrm{P}<0.001$ ) in the fresh tissues of Avicennia $(-27.18 \pm 1.15 \%)$ than in those of Rhizophora $(-29.60 \pm 2.12 \% 0)$. For both species, the $\mathrm{C} / \mathrm{N}$ ratios of the leaves were lower than those of the roots and the wood (Table 1). However, no significant differences in the $\delta^{15} \mathrm{~N}$ value were determined between the two species for any tissues (Student's $t$-test, $\mathrm{t}(16)=-0.47, \mathrm{P}>0.05$ ).
Table 1

Vegetation characteristics of the $A$. marina and $R$. spp. stands in the studied mangrove swamp: tree density (stem ha ${ }^{-1}$ ), tree height $(\mathrm{cm}), \delta^{13} \mathrm{C}$ and $\delta^{15} \mathrm{~N}$ $(\%)$ values and $\mathrm{C} / \mathrm{N}$ ratios. Values are means $\pm \mathrm{SD}$.

\begin{tabular}{lll}
\hline Source & A. marina & $R$. spp. \\
\hline Stem density $\left(\mathrm{NB} \mathrm{ha}{ }^{-1}\right)$ & $7167 \pm 815$ & $3667 \pm 1172$ \\
Tree height $(\mathrm{cm})$ & $79 \pm 55(n=215)$ & $263 \pm 42(n=110)$ \\
$\delta^{13} \mathrm{C}(\%)$ & & \\
$\quad$ Leaves $(n=3)$ & $-28.36 \pm 0.55$ & $-30.46 \pm 0.30$ \\
$\quad$ Roots $(n=3)$ & $-27.14 \pm 0.69$ & $-31.16 \pm 0.84$ \\
Wood $(n=3)$ & $-26.06 \pm 0.26$ & $-27.19 \pm 0.38$ \\
$\delta^{15} \mathrm{~N}(\%)$ & & \\
Leaves $(n=3)$ & $2.77 \pm 0.18$ & $3.71 \pm 1.85$ \\
Roots $(n=3)$ & $3.89 \pm 0.25$ & $4.37 \pm 1.79$ \\
$\quad$ Wood $(n=3)$ & $5.30 \pm 0.88$ & $4.74 \pm 0.41$ \\
C/N & & \\
$\quad$ Leaves $(n=3)$ & $25.48 \pm 1.05$ & $66.22 \pm 0.44$ \\
Roots $(n=3)$ & $43.57 \pm 1.20$ & $70.35 \pm 3.81$ \\
Wood $(n=3)$ & $54.44 \pm 7.11$ & $147.96 \pm 1.71$ \\
\hline
\end{tabular}

Table 2

List of CFAMS radiocarbon dates and calibrated dates $(2 \sigma)$ using using OxCal version 4.3 (Bronk Ramsey, 2009) with the SHCal13 curve (Hogg et al., 2013). Values of ${ }^{14} \mathrm{C}$ age are given \pm the measurement uncertainty; calibration ranges are given with a $95.4 \%$ confidence interval.

\begin{tabular}{llllll}
\hline Core & Depth (cm) & ${ }^{14}$ C age (yrs BP) & $\begin{array}{l}\text { Cal. Range } \\
\text { (cal. yrs. BP) }\end{array}$ & $\begin{array}{l}\text { Median } \\
\text { age (cal. } \\
\text { yrs BP) }\end{array}$ & $\begin{array}{l}\text { NOSAMS } \\
\text { number }\end{array}$ \\
\hline LF1 & $65-70$ & $1520 \pm 25$ & $544-640$ & 592 & OS-130664 \\
& $260-265$ & $4940 \pm 20$ & $3638-3759$ & 3699 & OS-130665 \\
LF2 & $30-35$ & $3230 \pm 20$ & $1410-1510$ & 1460 & OS-132455 \\
& $135-140$ & $4120 \pm 15$ & $2495-2853$ & 2674 & OS-132454 \\
LF3 & $120-125$ & $755 \pm 15$ & $1271-1375$ & 1323 & OS-130690 \\
\hline
\end{tabular}

\subsection{Stratigraphic description and radiocarbon dating}

Stratigraphic description of the cores can be found in Fig. 2 and results of radiocarbon dating are reported in Table 2 and Fig. 2.

In the salt-flat, the hard substrate was reached at $265 \mathrm{~cm}$ and was dated at ca. 3699 cal. yrs BP. It was composed of sand and shells, some of them were fully preserved but most were debris. The upper $70 \mathrm{~cm}$ of the sedimentary column was constituted of undifferentiated clays. Between 70 and $265 \mathrm{~cm}$ depth, core was characterized by dark brown muddy sediments enriched in red woody debris. The limit between these two layers was dated at ca. 592 cal. yrs BP.

In the A. marina stand, the hard substrate was reached at $140 \mathrm{~cm}$, and was dated at ca. 2674 cal. yrs BP. This hard substrate had a similar composition as in the salt-flat. The upper $35 \mathrm{~cm}$ was constituted of brown sediments. Between 35 and $140 \mathrm{~cm}$ depth, core was characterized by dark-brown muddy sediments enriched in red woody debris. The limit between these two layers was dated at $c a .1460 \mathrm{cal}$. yrs BP.

In the $R$. spp. stand, the hard substrate was reached at $125 \mathrm{~cm}$ and dated at 1323 cal. yrs BP. Its composition was similar than for the two others stands, with sand and shells debris. Only one facies was found in the sedimentary column, from the surface to the depth of $125 \mathrm{~cm}$. It was composed of a muddy dark-brown sediment, enriched in red woody debris.

\subsection{Characteristics of $\mathrm{OM}$ in the sedimentary column}

The characteristics of the OM in the sedimentary column for the salt-flat zone, the $A$. marina stand, and the $R$. spp. stand, were plotted in two scatter plots: $\delta^{13} \mathrm{C} v$ s. $\mathrm{C} / \mathrm{N}$ and $\delta^{15} \mathrm{~N} v$ s. C/N (Fig. 3). For each stand, two groups were distinguished with the scatter plots, indicating a difference in the origin of the OM: one group for the top of the sediment column (group 1), and one group at the bottom (group 2). A MANOVA 

a) Salt-flat zone
b) A. marina stand
c) R. spp. stand

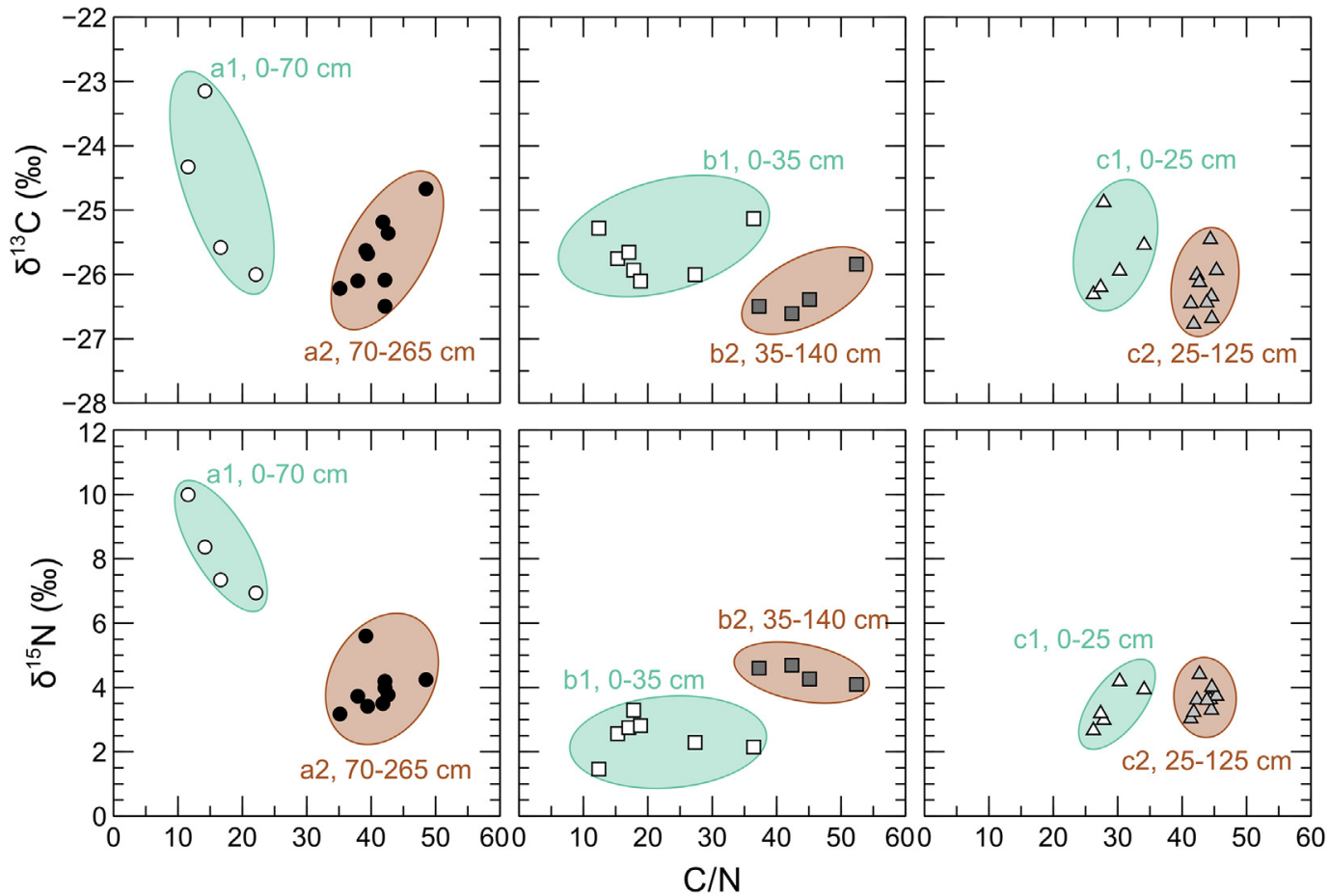

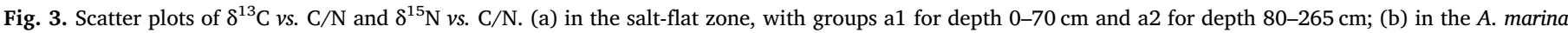

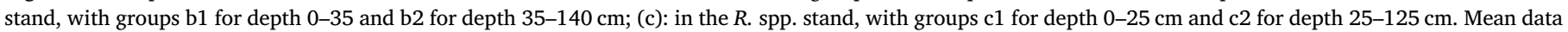
may be found in Table 3 and detailed values in Table 4.

Table 3

Mean values of $\mathrm{C} / \mathrm{N}$ ratio, $\delta^{13} \mathrm{C}(\%)$ and $\delta^{15} \mathrm{~N}(\%)$ in function of the stand, and of group depth (cm) as presented in Fig. 3.

\begin{tabular}{|c|c|c|c|c|c|}
\hline Stand & group & Depth $(\mathrm{cm})$ & $\mathrm{C} / \mathrm{N}$ & $\delta^{13} \mathrm{C}(\% 0)$ & $\delta^{15} \mathrm{~N}(\% 0)$ \\
\hline \multirow[t]{2}{*}{ Salt-flat } & a1 & $0-70$ & $16.12 \pm 4.49$ & $-24.76 \pm 1.29$ & $8.16 \pm 1.36$ \\
\hline & a2 & $70-265$ & $40.99 \pm 3.74$ & $-25.71 \pm 0.58$ & $3.96 \pm 0.71$ \\
\hline \multirow[t]{2}{*}{ A. marina } & b1 & $0-35$ & $20.74 \pm 8.31$ & $-25.69 \pm 0.37$ & $2.47 \pm 0.58$ \\
\hline & b2 & $35-140$ & $44.28 \pm 6.31$ & $-26.30 \pm 0.34$ & $4.41 \pm 0.28$ \\
\hline \multirow[t]{2}{*}{$R$. spp. } & $\mathrm{c} 1$ & $0-25$ & $29.16 \pm 3.14$ & $-25.77 \pm 0.58$ & $3.39 \pm 0.65$ \\
\hline & $\mathrm{c} 2$ & $25-125$ & $43.43 \pm 1.43$ & $-26.24 \pm 0.41$ & $3.62 \pm 0.42$ \\
\hline
\end{tabular}

analysis, with $\delta^{13} \mathrm{C}, \delta^{15} \mathrm{~N}$ and $\mathrm{C} / \mathrm{N}$ as variables, showed that the two groups were significantly different in each stand $(\mathrm{P}<0.01)$. Mean values of $\mathrm{C} / \mathrm{N}$ ratios, $\delta^{13} \mathrm{C}$ and $\delta^{15} \mathrm{~N}$ for groups 1 and 2 for each stand are presented in Table 3 and detailed values can be found in Table 4. Considering group 2 in the three cores, no significant differences of $\mathrm{C} / \mathrm{N}$ ratios, $\delta^{13} \mathrm{C}$ and $\delta^{15} \mathrm{~N}$ were observed between the stands (ANOVA, $\left.\mathrm{F}_{(2,19)}=1.57, \mathrm{P}>0.05\right)$. These two groups allowed to determine a limit between an upper layer, which is under the influence of the development of the current living forest, and a buried layer that is related to the development of a former mangrove forest. In the salt-flat zone, being characterized by an absence of vegetation, only the deep layer was considered, from 70 to $265 \mathrm{~cm}$ depth. For A. marina and R. spp. stands, the limits between the two groups were 35 and $25 \mathrm{~cm}$ depth, respectively.

\subsection{Carbon concentrations in the sediment and carbon stocks}

Concerning the salt-flat zone, the distribution of TOC, DBD and CD are characterized by two modes from the surface to the bottom of the sediment core with relatively invariant values within each mode (Table 4). From the top to $70 \mathrm{~cm}$ depth, mean values of $1.54 \pm 0.56 \%$, $0.69 \pm 0.09 \mathrm{~g} \mathrm{~cm}^{-3}$ and $1.09 \pm 0.49 \mathrm{gC} \mathrm{cm}^{-3}$ were measured for TOC, DBD, and CD, respectively. From $100 \mathrm{~cm}$ to $265 \mathrm{~cm}$ depth, mean values of TOC and CD were significantly higher (TOC, $t(8)=-12.14$, $\mathrm{P}<0.001 ; \mathrm{CD}, \mathrm{t}(8)=-6.19, \mathrm{P}<0.001)$ with mean values of $9.81 \pm 1.12 \%$ and $0.30 \pm 0.03 \mathrm{~g} \mathrm{~cm}^{-3}$, respectively; while mean values of DBD were significantly lower (DBD, $\mathrm{t}(11)=11.64, \mathrm{P}<0.001)$, with a mean value of $3.04 \pm 0.57 \mathrm{gC} \mathrm{cm}^{-3}$.

Concerning the $A$. marina stand, TOC and DBD mean values were $6.25 \pm 1.92 \%$ and $0.40 \pm 0.04 \mathrm{~g} \mathrm{~cm}^{-3}$ from the surface to $35 \mathrm{~cm}$ depth. Then, TOC increased to $11.27 \%$ at $62.5 \mathrm{~cm}$ and finally decreased to $5.68 \%$ at the bottom of the core (Table 4). From $35 \mathrm{~cm}$ to $140 \mathrm{~cm}$, mean DBD value was $0.31 \pm 0.05 \mathrm{~g} \mathrm{~cm}^{-3}$ (Table 4).

For the $R$. spp. stand, TOC and CD rapidly decreased in the upper $15 \mathrm{~cm}$, from $11.08 \%$ to $5.47 \%$ and from 3.76 to $2.09 \mathrm{gC} \mathrm{cm}^{-3}$, respectively. TOC and CD then peaked to $10.95 \%$ and 4.09 at $22.5 \mathrm{~cm}$ depth. TOC and CD values then gradually decreased to $82.5 \mathrm{~cm}$ depth, and thereafter remained relatively invariant to the bottom of the core, with mean values of $6.25 \pm 0.13 \%$ and $2.50 \pm 0.18 \mathrm{gC} \mathrm{cm}^{-3}$, respectively (Table 4). Mean value of DBD throughout the core was $0.40 \pm 0.03 \mathrm{~g} \mathrm{~cm}^{-3}$ (Table 4).

For the three cores, TIC was different from zero only at depths 260 to 265,130 to 140 , and 105 to $125 \mathrm{~cm}$ in the salt-flat zone, the $A$. marina stand, and the $R$. spp. stand, respectively (Table 4).

Integrating down to the hard substrate, sediment carbon stocks were 747.33 $\mathrm{MgC} \mathrm{ha}^{-1}, 344.64 \mathrm{MgC} \mathrm{ha}^{-1}$ and $378.91 \mathrm{MgC} \mathrm{ha}^{-1}$ for the salt- 
Table 4

Detailed values of TOC (\%), TIC (\%), DBD $\left(\mathrm{g} \mathrm{cm}^{-3}\right), \mathrm{CD}\left(\mathrm{gC} \mathrm{cm}^{-3}\right), \delta^{15} \mathrm{~N}(\%), \delta^{13} \mathrm{C}(\%)$ and $\mathrm{C} / \mathrm{N}$ for each cores in function of depth. Concerning depths 2.5 to $42.5 \mathrm{~cm}$ for TOC, TIC, DBD and CD, values are means of three replicates \pm SD.

\begin{tabular}{|c|c|c|c|c|c|c|c|}
\hline Sampling depth (cm) & TOC (\%) & TIC (\%) & $\operatorname{DBD}\left(\mathrm{g} \mathrm{cm}^{-3}\right)$ & $\mathrm{CD}\left(\mathrm{gC} \mathrm{cm}^{-3}\right)$ & $\delta^{15} \mathrm{~N}(\% 0)$ & $\delta^{13} \mathrm{C}(\%)$ & $\mathrm{C} / \mathrm{N}$ \\
\hline \multicolumn{8}{|l|}{ LF1, Salt-flat } \\
\hline 2.5 & $1.71 \pm 0.68$ & 0.00 & $0.65 \pm 0.03$ & $1.11 \pm 0.46$ & 9.99 & -24.33 & 11.57 \\
\hline 12.5 & $2.39 \pm 0.16$ & 0.00 & $0.82 \pm 0.08$ & $1.96 \pm 0.30$ & - & - & - \\
\hline 22.5 & $1.51 \pm 0.49$ & 0.00 & $0.78 \pm 0.12$ & $1.15 \pm 0.23$ & - & - & - \\
\hline 27.5 & - & - & - & - & 8.36 & -23.15 & 14.19 \\
\hline 32.5 & $1.73 \pm 0.88$ & 0.00 & $0.60 \pm 0.17$ & $0.99 \pm 0.43$ & - & - & - \\
\hline 42.5 & $0.78 \pm 0.21$ & 0.00 & $0.68 \pm 0.07$ & $0.52 \pm 0.08$ & - & - & - \\
\hline 57.5 & 1.10 & 0.00 & 0.64 & 0.80 & 7.34 & -25.58 & 16.62 \\
\hline 72.5 & 4.77 & 0.00 & 0.39 & 1.81 & 6.94 & -26.00 & 22.10 \\
\hline 82.5 & 10.30 & 0.00 & 0.38 & 4.27 & 5.60 & -25.63 & 39.17 \\
\hline 97.5 & 15.57 & 0.00 & 0.33 & 5.54 & 4.24 & -24.67 & 48.51 \\
\hline 112.5 & 11.62 & 0.00 & 0.28 & 3.42 & 3.50 & -25.18 & 41.81 \\
\hline 137.5 & 9.78 & 0.00 & 0.31 & 3.18 & 3.41 & -25.68 & 39.45 \\
\hline 157.5 & 8.16 & 0.00 & 0.24 & 2.28 & 3.17 & -26.22 & 35.15 \\
\hline 182.5 & 8.87 & 0.00 & 0.31 & 2.87 & 3.73 & -26.10 & 37.92 \\
\hline 207.5 & 10.41 & 0.00 & 0.32 & 3.60 & 4.19 & -26.09 & 42.13 \\
\hline 232.5 & 10.28 & 0.00 & 0.34 & 3.63 & 3.99 & -26.49 & 42.14 \\
\hline 262.5 & 9.55 & 0.56 & 0.27 & 2.34 & 3.77 & -25.36 & 42.63 \\
\hline \multicolumn{8}{|l|}{ LF2, A. marina } \\
\hline 2.5 & $7.64 \pm 1.21$ & 0.00 & $0.33 \pm 0.10$ & $2.46 \pm 0.43$ & 1.46 & -25.28 & 12.38 \\
\hline 7.5 & $5.10 \pm 2.07$ & 0.00 & $0.45 \pm 0.10$ & $2.16 \pm 0.61$ & 2.56 & -25.75 & 15.31 \\
\hline 12.5 & $5.32 \pm 1.49$ & 0.00 & $0.43 \pm 0.04$ & $2.24 \pm 0.46$ & 3.29 & -25.93 & 17.80 \\
\hline 17.5 & $5.98 \pm 2.55$ & 0.00 & $0.41 \pm 0.07$ & $2.31 \pm 0.61$ & 2.75 & -25.66 & 17.05 \\
\hline 22.5 & $5.10 \pm 1.91$ & 0.00 & $0.40 \pm 0.08$ & $1.95 \pm 0.32$ & 2.81 & -26.10 & 18.86 \\
\hline 27.5 & $7.05 \pm 1.12$ & 0.00 & $0.38 \pm 0.05$ & $2.73 \pm 0.72$ & 2.29 & -26.00 & 27.33 \\
\hline 32.5 & $7.56 \pm 2.78$ & 0.00 & $0.35 \pm 0.08$ & $2.47 \pm 0.52$ & - & - & - \\
\hline 37.5 & $10.79 \pm 1.95$ & 0.00 & $0.31 \pm 0.05$ & $3.35 \pm 0.78$ & 2.15 & -25.13 & 36.43 \\
\hline 42.5 & $10.52 \pm 1.31$ & 0.00 & $0.28 \pm 0.02$ & $2.95 \pm 0.28$ & - & - & - \\
\hline 62.5 & $11.53 \pm 1.12$ & 0.00 & $0.24 \pm 0.04$ & $2.83 \pm 0.74$ & 4.09 & -25.84 & 52.40 \\
\hline 87.5 & 7.67 & 0.00 & 0.27 & 2.00 & 4.26 & -26.39 & 45.10 \\
\hline 112.5 & 5.59 & 0.00 & 0.33 & 2.07 & 4.60 & -26.50 & 37.27 \\
\hline 132.5 & - & 1.73 & - & - & - & - & - \\
\hline 137.5 & 5.68 & 1.64 & 0.39 & 1.90 & 4.69 & -26.61 & 42.37 \\
\hline \multicolumn{8}{|l|}{ LF3, Rhizophora spp. } \\
\hline 2.5 & $11.08 \pm 3.71$ & 0.00 & $0.33 \pm 0.03$ & $3.76 \pm 1.09$ & 2.99 & -24.88 & 27.83 \\
\hline 7.5 & $5.47 \pm 1.50$ & 0.00 & $0.38 \pm 0.06$ & $2.09 \pm 0.38$ & 2.66 & -26.31 & 26.22 \\
\hline 12.5 & $5.84 \pm 0.22$ & 0.00 & $0.44 \pm 0.13$ & $2.56 \pm 0.70$ & 3.19 & -26.20 & 27.35 \\
\hline 17.5 & $7.85 \pm 2.45$ & 0.00 & $0.40 \pm 0.08$ & $3.05 \pm 0.63$ & 4.19 & -25.94 & 30.30 \\
\hline 22.5 & $10.95 \pm 3.81$ & 0.00 & $0.38 \pm 0.07$ & $4.10 \pm 1.37$ & 3.93 & -25.54 & 34.10 \\
\hline 27.5 & $10.02 \pm 2.17$ & 0.00 & $0.38 \pm 0.09$ & $3.76 \pm 0.09$ & 3.62 & -25.45 & 44.38 \\
\hline 32.5 & - & 0.00 & - & - & 3.73 & -25.94 & 45.34 \\
\hline 37.5 & $8.94 \pm 1.35$ & 0.00 & $0.40 \pm 0.12$ & $3.54 \pm 0.52$ & 3.61 & -26.01 & 42.29 \\
\hline 42.5 & - & 0.00 & - & - & 3.30 & -26.34 & 44.55 \\
\hline 47.5 & $10.59 \pm 3.20$ & 0.00 & $0.38 \pm 0.12$ & $3.93 \pm 0.76$ & 3.60 & -26.44 & 43.84 \\
\hline 62.5 & 8.68 & 0.00 & 0.39 & 3.27 & 3.03 & -26.45 & 41.34 \\
\hline 82.5 & 6.40 & 0.00 & 0.39 & 2.57 & 3.23 & -26.77 & 41.80 \\
\hline 102.5 & 6.16 & 0.00 & 0.43 & 2.64 & 4.01 & -26.68 & 44.62 \\
\hline 107.5 & - & 0.35 & - & - & - & - & - \\
\hline 117.5 & - & 0.55 & - & - & - & - & - \\
\hline 122.5 & 6.19 & 0.44 & 0.41 & 2.29 & 4.41 & -26.12 & 42.70 \\
\hline
\end{tabular}

flat zone, the A. marina stand and the $R$. spp. stand, respectively (Fig. 4). Then, integrating the top meter of sediment under the living forest, carbon stocks were 255.48 and $314.57 \mathrm{MgC} \mathrm{ha}^{-1}$ for A. marina and $R$. spp., respectively (Fig. 4 ). When considering the limit reached by the organic matter of the current forest, determined using the sedimentological aspects of the cores and the vertical distribution of $\mathrm{C} / \mathrm{N}$ ratios and stable isotopes $\delta^{13} \mathrm{C}$ and $\delta^{15} \mathrm{~N}$, sediment carbon stocks were integrated from the top of the sediment column to $35 \mathrm{~cm}$ depth in the $A$. marina stand and to $25 \mathrm{~cm}$ depth in the $R$. spp. stand. Therefore, sediment carbon stocks in the layer under the influence of the current forest were $81.02 \mathrm{MgC} \mathrm{ha}^{-1}$ and $77.79 \mathrm{MgC} \mathrm{ha}^{-1}$ for A. marina and $R$. spp., respectively (Fig. 4). Regarding the buried layer, sediment carbon stocks were $665.36 \mathrm{MgC} \mathrm{ha}^{-1}, 256.12 \mathrm{MgC} \mathrm{ha}^{-1}$ and $301.12 \mathrm{MgC} \mathrm{ha}^{-1}$ for the salt-flat zone, the A. marina stand and the $R$. spp. stand, respectively (Fig. 4). Consequently, the buried layer represented $89.03 \%$, $74.32 \%$ and $79.47 \%$ of total stock for the salt-flat, the $A$. marina stand and the $R$. spp. stand, respectively.

\section{Discussion}

\subsection{OM characterization with depth and along the intertidal elevation gradient}

In mangrove sediments, OM may derive from various sources; mangrove leaves, roots, wood, microphytobenthos and benthic infauna are the main contributors, but allochthonous sources of marine or terrestrial origin may also contribute to the organic carbon pool to a lesser extent (Kristensen et al., 2008). To characterize OM in a complex mixture like mangrove sediments, a combination of different geochemical indicators is required. In the present study, the depth distribution of $\mathrm{C} / \mathrm{N}$ ratios and stable isotopes $\left(\delta^{13} \mathrm{C}\right.$ and $\left.\delta^{15} \mathrm{~N}\right)$ showed two distinct strata characterized by specific $\mathrm{OM}$ quantity and characteristics (Fig. 3, Tables 3 and 4).

In the upper layers, $\mathrm{C} / \mathrm{N}$ ratios and $\delta^{13} \mathrm{C}$ ranged between 10 and 40 and between -24 to $-27 \%$, respectively, being consistent with those 


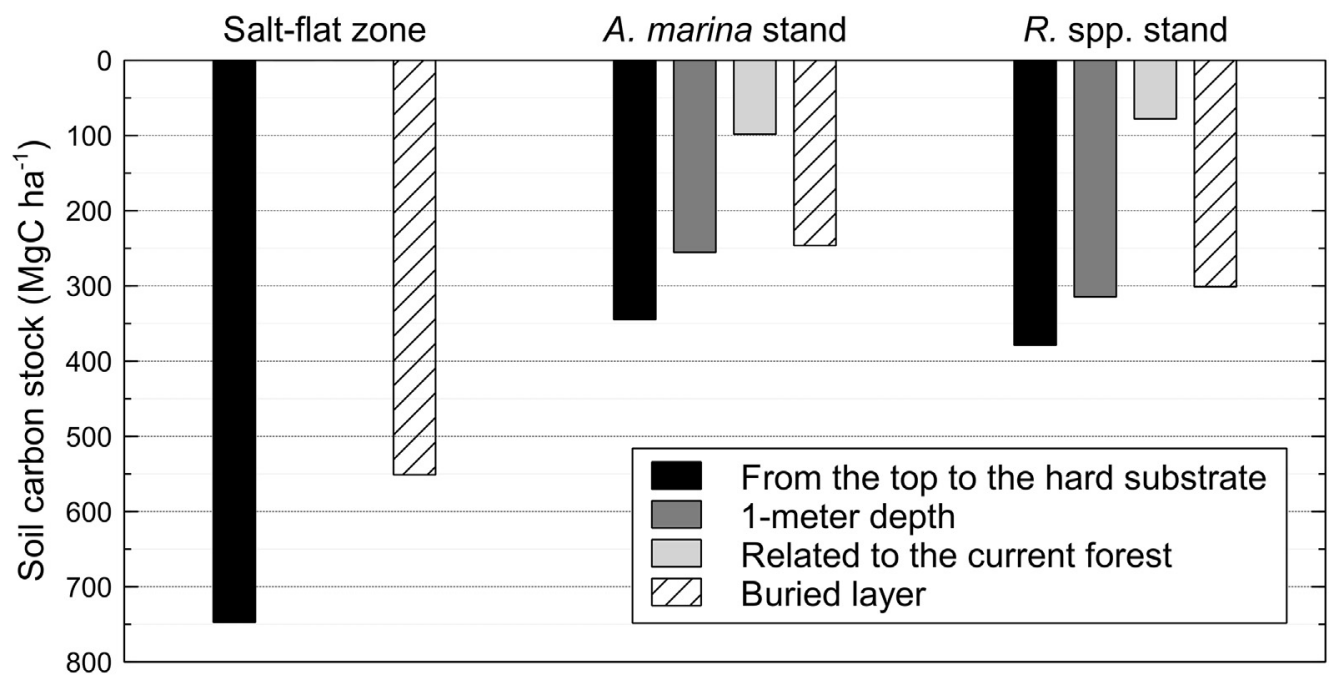

Fig. 4. Representation of the soil carbon stocks $\left(\mathrm{MgC} \mathrm{ha}^{-1}\right)$ for different sediment layers at the three zones: salt-flat, $A$. marina stand, and $R$. spp. stand. Concerning the stocks related to the current forest, carbon stocks were integrated from 0 to $35 \mathrm{~cm}$ and from 0 to $25 \mathrm{~cm}$ under $A$. marina and $R$. spp., respectively. Regarding the buried layer, carbon stocks were integrated from $70 \mathrm{~cm}$ to $265 \mathrm{~cm}$ in the salt-flat zone, from 35 to $140 \mathrm{~cm}$ in the A. marina stand, and from 25 to $125 \mathrm{~cm}$ in the $R$. spp. stand.

previously reported in mangrove sediments (Bouillon et al., 2003; Prasad et al., 2017). OM characteristics differed between the Avicennia and the Rhizophora stands, with notably higher $\mathrm{C} / \mathrm{N}$ ratios under $R$. spp. than under $A$. marina stand. This $\mathrm{C} / \mathrm{N}$ depletion under $A$. marina may result from different causes. First, the fresh tissues of $A$. marina typically had lower $\mathrm{C} / \mathrm{N}$ ratios than $R$. spp. (Table 1 ). Then, due to its intermediate position in the intertidal zone, A. marina is less subject to tidal flushing and thus might accumulate more leaf litter, characterized by low $\mathrm{C} / \mathrm{N}$ ratios, while $R$. spp. might accumulate more woody tissues with higher $\mathrm{C} / \mathrm{N}$ ratios (Table 1 ), the leaf litter being flushed away. In addition, surface sediments of $A$. marina may shelter a larger amount of microphytobenthos, having typical values of $\mathrm{C} / N<10$ (Lamb et al., 2006), due to an open canopy that allows light to reach the sediment surface (Leopold et al., 2013). Eventually, sediments beneath Rhizophora are more anoxic with long periods of immersion that prevents air diffusion from the atmosphere and thus limits OM decay processes, while upper sediments beneath Avicennia are usually oxic to suboxic due to air diffusion from the atmosphere into the sediment during the long emerged periods, and due to air diffusion from the specific root system (Alongi et al., 2000; Andersen and Kristensen, 1988; Marchand et al., 2004). The suboxic conditions beneath Avicennia stand may favor OM decomposition and thus $\mathrm{C} / \mathrm{N}$ decrease. Consequently, we suggest that the intertidal position of the mangrove stand, by controlling mangrove species distribution, tidal flushing and OM decay processes, has an influence on OM quantity and characteristics in mangrove sediments.

Whatever the stand, the deep layer was enriched in OM compared to the upper layer, with TOC concentrations up to $15 \%$, and was characterized by high $\mathrm{C} / \mathrm{N}$ ratios and low $\delta^{13} \mathrm{C}$ values, both typical of higher plant debris (Meyers and Lallier-Vergès, 1999). However, this layer extends down to the hard substrate, which was deeper than $1 \mathrm{~m}$ beneath the forested stands, and thus the accumulated OM in this layer cannot originate from the above forest. In mangroves, root systems usually develop between 20 and $60 \mathrm{~cm}$ depth, and never deeper than $1 \mathrm{~m}$ (Castañeda-Moya et al., 2011; Claus and George, 2005; Ferreira et al., 2007; Gill and Tomlinson, 1977; Komiyama et al., 2000; Ong et al., 2004; Tamooh et al., 2008). In addition, this organic-rich layer was also observed in the salt-flat, without any vegetation cover, and extends down to $260 \mathrm{~cm}$ depth. In fact, irrespective of the stand, this layer was visually enriched in red woody tissues, typical of Rhizophora tissues. Consequently, we suggest that the current living mangrove forest develops on sediments that were previously colonized by a Rhizophora forest. However, it was surprising to observe that OM in the buried layer was more preserved than in the upper layer beneath the Rhizophora stand, with $\delta^{13} \mathrm{C}$ values and $\mathrm{C} / \mathrm{N}$ ratios close to those of fresh root tissues (Table 1). In addition, the OM quantity was much higher. These two results may indicate that either the productivity of the former forest was higher, or that the conditions were more favorable to $\mathrm{OM}$ accumulation, e.g. more anoxic conditions (longer immersion time) or higher sedimentation rates. This buried organic-rich layer was already observed in different mangroves of the west coast of New Caledonia (Deborde et al., 2015; Marchand et al., 2011a, 2011b; Marchand et al., 2012), indicating that the cause may not be local but rather related to sea-level evolution in this region.

\subsection{Migration of the mangrove ecosystem down the intertidal zone}

The hard substrate reached beneath every stands stand was sandy, characterized by broken or fully preserved shells, and increased quantity of inorganic carbon (Table 4), which was null above. The presence of Rhizophora red woody tissues above these shells indicates a transition from a marine dominated system to a mangrove dominated ecosystem. The red woody debris collected just above the hard substrate in the three stands were dated at $c a .3700,2700$ and 1300 cal. yrs BP beneath the current salt-flat, $A$. marina and $R$. spp. stands, respectively. These results confirm a seaward migration of the mangrove (Fig. 5a, b and c). Our observations show that Rhizophora trees developed preferentially in the low intertidal zone, until $0.57 \mathrm{~cm}$ above MSL, whereas A. marina developed in the middle intertidal zone, between 0.52 and $0.69 \mathrm{~m}$ above MSL. Sediment salinity was recognized as the main factor controlling this distribution (Deborde et al., 2015; Marchand et al., 2012, 2011a), which is, in turn, directly linked to the sediment inundation and elevation, and thus to the current mean sea-level. The progressive colonization of Rhizophora downward the intertidal zone might be linked to a regular retreat in mean sea-level, starting before 3700 cal. yrs BP. The marine regression created new accommodation spaces at the mangrove front, allowing Rhizophora to colonize, leaving the less attractive upper intertidal zone, due to an increase in salt concentrations, to the benefit of A. marina. This pattern was observed in site LF2, where the Rhizophora forest lasted around 1200 cal. yrs before being colonized by A. marina ca. $1450 \mathrm{cal}$. yrs BP, which is still present at this position (Fig. $5 \mathrm{c}$ and $\mathrm{d}$ ). This hypothesis of a regular marine regression in New Caledonia is consistent with the theory developed by Cabioch et al. (1989), later reinvested by Mitrovica and Peltier (1991), or more recently by Yamano et al. (2014) and Nunn and Carson (2015). They notably showed that the sea-level was $\sim 1.1 \mathrm{~m}$ higher around $4500 \mathrm{cal} \mathrm{yr} \mathrm{BP}$, and that the sea-level fall at the latest since $2800 \mathrm{cal} \mathrm{yr}$ BP.

Site LF1 suggests that a Rhizophora mangrove forest was stable during $>3000$ years, before being replaced around $590 \mathrm{cal}$. yrs BP by 


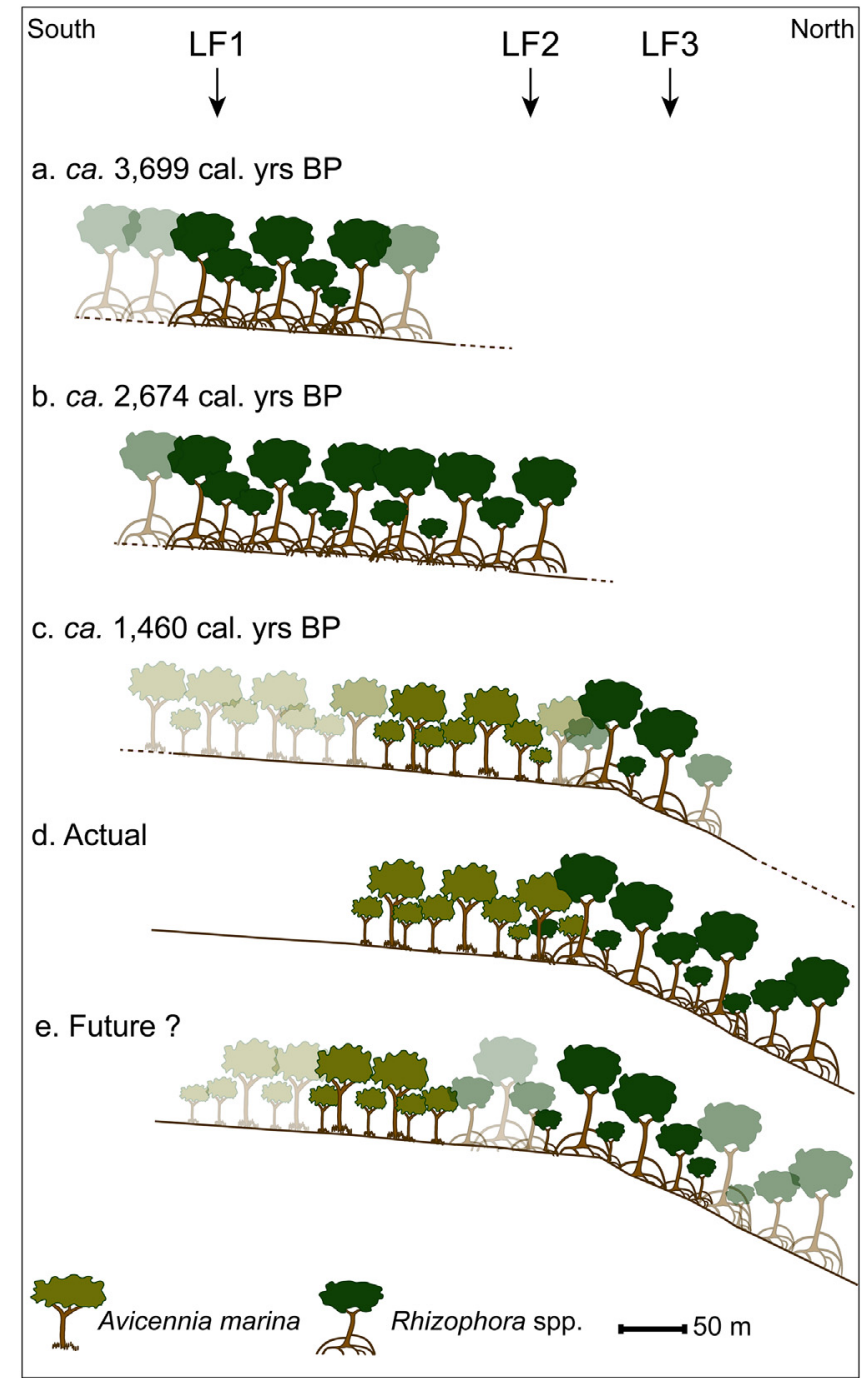

Fig. 5. Simplified illustration of the colonization phases of the actual mangrove swamp during the last 4000 years, and possible future evolution of the ecosystem. Shaded pictograms indicate uncertain presence of the mangrove species.

the actual salt-flat (Fig. 5d). This last establishment was due to a low sea-level that has induced low period of immersion resulting in elevated evaporation processes and, thus, too much salt in the sediment for mangrove development. No evidence of an establishment of $A$. marina forest was observed between the Rhizophora forest and the salt-flat, neither in the stratigraphic observations (Fig. 2), nor in the geochemical results (Fig. 3). Therefore, two hypotheses may be developed. First, a sharp sea-level drawdown around 590 cal. yrs BP, might have prevented the establishment of $A$. marina. This sea-level drawdown was described by Cabioch et al. (1989) and more recently by Wirrmann et al. (2011). However, the presence of $A$. marina in site LF2 since ca. 1450 cal. yrs $\mathrm{BP}$, suggests that this hypothesis cannot explain the absence of $A$. marina debris between the salt-flat sediment and the buried layer. As explained earlier, Avicennia sediments may favor OM decomposition due to their higher position and the oxygen released from their root system. In addition, Avicennia debris are less refractory to decomposition than Rhizophora ones, which contain abundant tannins (Kristensen et al., 2008). Therefore, we consider that Avicennia-derived OM may have been decomposed, and that other biomarkers (e.g. lignin-derived phenols or pollen) should be used to determine their presence. The continuous sea-level drop, and the fact that LF1 was the highest intertidal position, may have led to a short period of development of the
Avicennia forest at this position, which has resulted in low organic enrichment of the sediment, not visible with the parameters studied herein.

We are aware that the organic carbon dating in mangrove sediments can be quite difficult due to roots extension and fauna bioturbation (Woodroffe et al., 2016, 2015). However, as the woody debris collected in the present study were of pluri-centimetric size and in a horizontal position, we are confident with the results reported here, and with the evolution model presented above, which fits well with the sea-level evolution in New Caledonia described by the authors cited above. We, thus, suggest that the late Holocene marine regression induced a seaward migration of the mangrove forest, and was responsible of a buried layer enriched in Rhizophora tissues beneath every stand.

\subsection{Influence of mangrove seaward migration on sediment carbon stocks}

To determine sediment carbon stocks in mangrove, depth integration should be clearly discussed, as suggested by Lunstrum and Chen (2014). Thus, it is recommended to sample the sediment down to the bedrock, but, most of the time, the stocks are determined down to one meter deep. In the studied mangrove, integrating the top meter of sediment beneath $A$. marina and $R$. spp. stands resulted in sediment carbon stocks of 255 and $315 \mathrm{MgCha}^{-1}$, respectively, which is lower than the reported values for tropical mangroves, ranging from 337 to $640 \mathrm{MgC} \mathrm{ha}^{-1}$ (Adame et al., 2013; Castillo et al., 2017; DelVecchia et al., 2014; Hossain, 2014; Kauffman et al., 2011). Different climatic conditions may be the major explanation of this difference, as tropical mangroves are typically more productive than higher latitudinal mangroves (Alongi, 2012; Kristensen et al., 2008; Sanders et al., 2010). On the west coast of New Caledonia, climate is semi-arid, and mangrove trees are most of the time dwarf (Table 1). They suffer from the lack of water and have a limited productivity (Leopold et al., 2016), which may induce the lower sediment carbon stock values in comparison to tropical mangrove forests.

However, the visual observations of the cores, the $\mathrm{C} / \mathrm{N}$ and isotopic results showed that the root system mainly developed in the upper $40 \mathrm{~cm}$. Consequently, the stock down to $1 \mathrm{~m}$ is not only related to the development of the current forest, but also takes into account part of the buried layer enriched in Rhizophora debris, induced by the sea-level drop in the region. Therefore, comparing sediment carbon stocks integrated down to $1 \mathrm{~m}$ may not be relevant since it implies to sum stocks of different forests that developed when the mean sea-level was different. This result highlights the necessity to precisely define the objectives of the study before measuring sediment carbon stocks in highly dynamic ecosystems such as mangroves, and, if the objectives are to evaluate the effect of the current living forest on sediment carbon stocks, the vertical limit of the root system must be determined (Lunstrum and Chen, 2014; Marchand, 2017). Our results suggest that the upper sediment carbon stock is directly related to the living forest at the time of deposit, which is, in turn, related to the mean sea-level.

Taking into account the limits determined using $\mathrm{C} / \mathrm{N}$ ratios and isotopic values, the development of the current forest induced a slightly higher carbon stock under $A$. marina than under $R$. spp., with about 81 and $78 \mathrm{MgCha}^{-1}$, respectively. However, comparing carbon stocks between these two layers may be biased as the integration depth under $A$. marina was higher than under $R$. stylosa. When comparing mean carbon density, we found higher values under $R$. stylosa $\left(3.11 \pm 0.83 \mathrm{gC} \mathrm{cm}^{-3}\right)$ than under A. marina $\left(2.46 \pm 0.43 \mathrm{gC} \mathrm{cm}^{-3}\right.$, due to the higher productivity of Rhizophora trees in comparison to Avicennia trees (Komiyama et al., 2008), and the more oxic conditions of the sediment under Avicennia, as discussed earlier, enhancing the rate of OM decomposition.

Due to the integration of buried layers, resulting from mangrove development at different sea-level, sediment carbon stocks down to the bedrock were 3.5 and 4.8-fold higher than for the upper layer under $A$. marina and $R$. spp., respectively. Specifically, the sediment carbon stock 
in the buried layer beneath the salt-flat was higher than $665 \mathrm{MgC} \mathrm{ha}^{-1}$, and was more than twice those measured beneath $A$. marina and $R$. spp. In fact, the thickness of the buried layer beneath the salt-flat was almost $2 \mathrm{~m}$, which were deposited during $>3000$ years, during the relatively stable sea-level highstand before the drop. Beneath the Avicennia and the Rhizophora stands, the thicknesses of the buried layers were smaller, and $\mathrm{OM}$ accumulated during shorter periods, due to later mangrove colonization and continuous sea-level drop. Consequently, we suggest that periods of sea-level stability may result in high accumulation of organic peat in mangrove ecosystems.

Understanding the evolution of mangroves with sea-level variations and its implication on sediment carbon stocks is of major concern considering the prime importance of mangrove ecosystems in carbon storage (Donato et al., 2011). Global sea-level increased over recent decades and is predicted to increase from 0.26 to $0.98 \mathrm{~m}$ by the end of the 21st century (Church et al., 2013). The most probable evolution of the studied mangrove, if it cannot keep pace with sea-level rise, is a landward migration to the upper intertidal area, resulting in the installation of Avicennia and Rhizophora stands on the current salt-flat and A. marina stands, respectively (Fig. 5e). However, while this inland migration of the mangrove may be possible in New Caledonia, due to spaces availability at the back of mangroves, this retreat may be more difficult in other locations as in developing countries, where coastal squeeze may be important due to strong urban development. In the latter case, other scenarios have to be considered for these mangroves that will be directly affected by the increase in sea-level.

\section{Conclusion}

The present study aimed to evaluate sediment carbon stocks along an intertidal gradient in a zoned mangrove growing under the semi-arid climate of New Caledonia and to identify a possible influence of sealevel evolution during the Holocene on these stocks. Our main results can be summarized as follow:

- The sediment under the three studied mangrove stands could be separated in two different layers, according to depth. The top layer extended from the surface to 70,35 and $25 \mathrm{~cm}$ depth in the salt-flat, the Avicennia and the Rhizophora stands, respectively, while the bottom part extended down to the hard-sandy substrate, at 265, 140 and $125 \mathrm{~cm}$ depth, respectively.

- The limits between these layers were identified using a combination of different markers as stratigraphic observations, and the distribution of $\mathrm{C} / \mathrm{N}$ ratio and stable isotopes $\delta^{13} \mathrm{C}$ and $\delta^{15} \mathrm{~N}$. The large proportion of red woody tissues found in the deep layers suggests that these horizons result from the development of a Rhizophora forest, now disappeared.

- The organic material collected just above the hard substrate revealed younger ages when progressing downward the intertidal zone. We suggested that the marine regression of the late Holocene leaded to a downward colonization of the intertidal zone by the mangrove. Rhizophora colonized firstly, later followed by Avicennia when the sea-level was too low for Rhizophora to develop.

- This evolution of the mangrove with sea-level fall influenced mainly the evaluation of sediment carbon stocks. Integrating down from the surface to the hard substrate leaded to take into account the former mangrove, and thus, considerably increased the sediment carbon stock. Integrating only the top meter of sediment, as it is commonly observed in other studies, led to an under-estimation of the stocks. Conversely, over-estimation of the stocks can occur when integrating the top meter to evaluate the effect of the development of the current forest. In this case, we suggest that the vertical limit of the root system of the surface vegetation has to be precisely defined before determining the carbon stocks.

- Future research will be now needed to evaluate the evolution of the mangrove during the mid-Holocene marine transgression, and its effect on sediment carbon stocks. As sea-level rose during midHolocene, a carbon rich sediment probably formed, now buried under the hard substrate found in this study. This future study could help to understand how past sea-level rise influenced the evolution of the mangrove, and thus, sediment carbon stocks, and therefore help to understand the future evolution of the mangrove with projected sea-level rise.

\section{Acknowledgments}

This work was supported by the Southern Province of New Caledonia, the City of Mont Dore, KNS Koniambo Nickel SAS. We gratefully thank Ryan Venturelli for handled the radiocarbon analysis. In memory of Professor Eugene W. Domack (1956-2017), outstanding man and scientist, who recently passed away.

\section{Declaration of interest}

Authors have no conflict of interest to declare.

\section{References}

Adame, M.F., Kauffman, J.B., Medina, I., Gamboa, J.N., Torres, O., Caamal, J.P., Reza, M., Herrera-Silveira, J.A., 2013. Carbon stocks of tropical coastal wetlands within the karstic landscape of the Mexican Caribbean. PLoS ONE 8, e56569. https://doi.org/ 10.1371/journal.pone.0056569.

Alongi, D.M., 2012. Carbon sequestration in mangrove forests. Carbon Manage. 3, 313-322. https://doi.org/10.4155/cmt.12.20.

Alongi, D.M., Tirendi, F., Clough, B.F., 2000. Below-ground decomposition of organic matter in forests of the mangroves Rhizophora stylosa and Avicennia marina along the arid coast of Western Australia. Aquat. Bot. 68, 97-122.

Andersen, F., Kristensen, E., 1988. Oxygen microgradients in the rhizosphere of the mangrove Avicennia marina. Mar. Ecol. Prog. Ser. 44, 201-204. https://doi.org/10. 3354/meps044201.

Baltzer, F., 1970. Absolute dating of holocene transgression on the west coast of New Caledonia carried out on samples of mangrove peat. Neotectonic interpretation. Compt. Rend., Ser. D 271, 2251-2254.

Baltzer, F., 1982. Géodynamique de la sédimentation et diagenèse précoce en domaine ultrabasique: Nouvelle-Calédonie, Travaux et Documents de l'ORSTOM. ORSTOM, Paris.

Behling, H., da Costa, M.L., 2001. Holocene vegetational and coastal environmental changes from the Lago Crispim record in northeastern Pará State, eastern Amazonia. Rev. Palaeobot. Palynol. 114, 145-155.

Bouillon, S., Dahdouh-Guebas, F., Rao, A., Koedam, N., Dehairs, F., 2003. Sources of organic carbon in mangrove sediments: variability and possible ecological implications. Hydrobiologia 495, 33-39.

Bouillon, S., Borges, A.V., Castañeda-Moya, E., Diele, K., Dittmar, T., Duke, N.C., Kristensen, E., Lee, S.Y., Marchand, C., Middelburg, J.J., et al., 2008. Mangrove production and carbon sinks: a revision of global budget estimates. Glob. Biogeochem. Cycles 22.

Breithaupt, J.L., Smoak, J.M., Smith, T.J., Sanders, C.J., Hoare, A., 2012. Organic carbon burial rates in mangrove sediments: strengthening the global budget: mangrove organic carbon burial rates. Glob. Biogeochem. Cycles 26. https://doi.org/10.1029/ 2012 GB004375.

Bronk Ramsey, C., 2009. Bayesian analysis of radiocarbon dates. Radiocarbon 51, 337-360. https://doi.org/10.1017/S0033822200033865.

Cabioch, G., Thomassin, A., Lecolle, F.L., 1989. Age d'émersion des récifs frangeants holocènes autour de la (< Grande Terre) de Nouvelle-Calédonie (SO Pacifique); nouvelle interprétation de la courbe des niveaux marins depuis 8000 ans BP. Acad. Sci. Paris 308, 419-425.

Cabioch, G., Wirrmann, D., Sémah, A.-M., Corrège, T., Le Cornec, F., 2008. Évolution des paléoenvironnements dans le Pacifique lors de la dernière déglaciation: exemples en Nouvelle-Calédonie et au Vanuatu. J. Soc. Océan. 25-40. https://doi.org/10.4000/ jso.4482.

Castañeda-Moya, E., Twilley, R.R., Rivera-Monroy, V.H., Marx, B.D., Coronado-Molina, C., Ewe, S.M.L., 2011. Patterns of root dynamics in mangrove forests along environmental gradients in the Florida Coastal Everglades, USA. Ecosystems 14, 1178-1195. https://doi.org/10.1007/s10021-011-9473-3.

Castillo, J.A.A., Apan, A.A., Maraseni, T.N., Salmo, S.G., 2017. Soil C quantities of mangrove forests, their competing land uses, and their spatial distribution in the coast of Honda Bay, Philippines. Geoderma 293, 82-90. https://doi.org/10.1016/j. geoderma.2017.01.025.

Church, J.A., Clark, P.U., Cazenave, A., Gregory, J.M., Jevrejeva, S., Levermann, A, Merrifield, M.A., Milne, G.A., Nerem, R.S., Nunn, P.D., Payne, A.J., 2013. Sea level change. In: Stocker, T.F., Qin, D., Plattner, G.-K., Tignor, M., Allen, S.K., Boschung, J., Nauels, A., Xia, Y., Bex, V., Midgley, P.M. (Eds.), Climate Change 2013: The Physical Science Basis. Contribution of Working Group I to the Fifth Assessment Report of the Intergovernmental Panel on Climate Change. PM Cambridge University Press.

Claus, A., George, E., 2005. Effect of stand age on fine-root biomass and biomass 
distribution in three European forest chronosequences. Can. J. For. Res. 35, 1617-1625. https://doi.org/10.1139/x05-079.

Deborde, J., Marchand, C., Molnar, N., Patrona, L.D., Meziane, T., 2015. Concentrations and fractionation of carbon, iron, sulfur, nitrogen and phosphorus in mangrove sediments along an intertidal gradient (semi-arid climate, New Caledonia). J. Mar. Sci. Eng. 3, 52-72. https://doi.org/10.3390/jmse3010052.

DelVecchia, A.G., Bruno, J.F., Benninger, L., Alperin, M., Banerjee, O., Morales, J. de D., 2014. Organic carbon inventories in natural and restored Ecuadorian mangrove forests. PeerJ 2, e388. https://doi.org/10.7717/peerj.388.

Dittmar, T., Lara, R.J., 2001. Molecular evidence for lignin degradation in sulfate-reducing mangrove sediments (Amazonia, Brazil). Geochim. Cosmochim. Acta 65, 1417-1428.

Donato, D.C., Kauffman, J.B., Murdiyarso, D., Kurnianto, S., Stidham, M., Kanninen, M., 2011. Mangroves among the most carbon-rich forests in the tropics. Nat. Geosci. 4, 293-297. https://doi.org/10.1038/ngeo1123.

Ellison, J.C., 2008. Long-term retrospection on mangrove development using sediment cores and pollen analysis: a review. Aquat. Bot. Mangrove Ecol. Appl. For. Coast. Zone Manage. 89, 93-104. https://doi.org/10.1016/j.aquabot.2008.02.007.

Engelhart, S.E., Horton, B.P., Roberts, D.H., Bryant, C.L., Corbett, D.R., 2007. Mangrove pollen of Indonesia and its suitability as a sea-level indicator. Mar. Geol. 242, 65-81.

Ezcurra, P., Ezcurra, E., Garcillán, P.P., Costa, M.T., Aburto-Oropeza, O., 2016. Coastal landforms and accumulation of mangrove peat increase carbon sequestration and storage. PNAS 113, 4404-4409. https://doi.org/10.1073/pnas.1519774113.

Ferreira, T.O., Otero, X.L., Vidal-Torrado, P., Macías, F., 2007. Effects of bioturbation by root and crab activity on iron and sulfur biogeochemistry in mangrove substrate. Geoderma 142, 36-46. https://doi.org/10.1016/j.geoderma.2007.07.010.

França, M.C., Cohen, M.C.L., Pessenda, L.C.R., Rossetti, D.F., Lorente, F.L., Buso Junior, A.Á., Guimarães, J.T.F., Friaes, Y., Macario, K., 2013. Mangrove vegetation changes on Holocene terraces of the Doce River, southeastern Brazil. Catena 110, 59-69. https://doi.org/10.1016/j.catena.2013.06.011.

França, M.C., Alves, I.C.C., Cohen, M.C., Rossetti, D.F., Pessenda, L.C., Giannini, P.C., Lorente, F.L., Buso Junior, A.Á., Bendassolli, J.A., Macario, K., 2016. Millennial to secular time-scale impacts of climate and sea-level changes on mangroves from the Doce River delta, Southeastern Brazil. The Holocene 26, 1733-1749. https://doi.org/ 10.1177/0959683616645938.

Freudenthal, T., Wagner, T., Wenzhöfer, F., Zabel, M., Wefer, G., 2001. Early diagenesis of organic matter from sediments of the eastern subtropical Atlantic: evidence from stable nitrogen and carbon isotopes. Geochim. Cosmochim. Acta 65, 1795-1808. https://doi.org/10.1016/S0016-7037(01)00554-3.

Fujimoto, K., Miyagi, T., Kikuchi, T., Kawana, T., 1996. Mangrove habitat formation and response to Holocene sea-level changes on Kosrae Island, Micronesia. Mangrove Salt Marshes 1, 47-57.

Gill, A.M., Tomlinson, P.B., 1977. Studies on the growth of red mangrove (Rhizophora mangle L.) 4. The adult root system. Biotropica 9, 145. https://doi.org/10.2307/ 2387877.

Gilman, E.L., Ellison, J., Duke, N.C., Field, C., 2008. Threats to mangroves from climate change and adaptation options: a review. Aquat. Bot. Mangrove Ecol. Appl. For. Coastal Zone Manage. 89, 237-250. https://doi.org/10.1016/j.aquabot.2007.12.009.

Ha, T.H., Marchand, C., Aimé, J., Dang, H.N., Phan, N.H., Nguyen, X.T., Nguyen, T.K.C., 2017. Belowground carbon sequestration in a mature planted mangroves (Northern Viet Nam). For. Ecol. Manag. https://doi.org/10.1016/j.foreco.2017.06.057.

Hait, A.K., Behling, H., 2009. Holocene mangrove and coastal environmental changes in the western Ganga-Brahmaputra Delta, India. Veg. Hist. Archaeobotany 18, 159-169. https://doi.org/10.1007/s00334-008-0203-5.

Hogg, A.G., Hua, Q., Blackwell, P.G., Niu, M., Buck, C.E., Guilderson, T.P., Heaton, T.J., Palmer, J.G., Reimer, P.J., Reimer, R.W., Turney, C.S.M., Zimmerman, S.R.H., 2013. SHCal13 southern hemisphere calibration, 0-50,000 years cal BP. Radiocarbon 55, 1889-1903. https://doi.org/10.2458/azu js rc.55.16783.

Horton, B.P., Gibbard, P.L., Mine, G.M., Morley, R.J., Purintavaragul, C., Stargardt, J.M., 2005. Holocene sea levels and palaeoenvironments, Malay-Thai Peninsula, southeast Asia. The Holocene 15, 1199-1213.

Hossain, M., 2014. Carbon pools and fluxes in Bruguiera parviflora dominated naturally growing mangrove forest of Peninsular Malaysia. Wetl. Ecol. Manag. 22, 15-23. https://doi.org/10.1007/s11273-013-9318-2.

Joo-Chang, J.C., Islebe, G.A., Torrescano-Valle, N., 2015. Mangrove history during middle- and late-Holocene in Pacific south-eastern Mexico. The Holocene 25, 651-662. https://doi.org/10.1177/0959683614566217.

Kauffman, J.B., Donato, D.C., 2012. Protocols for the Measurement, Monitoring and Reporting of Structure, Biomass, and Carbon Stocks in Mangrove Forests. Citeseer.

Kauffman, J.B., Heider, C., Cole, T.G., Dwire, K.A., Donato, D.C., 2011. Ecosystem carbon stocks of micronesian mangrove forests. Wetlands 31, 343-352. https://doi.org/10. 1007/s13157-011-0148-9.

Komiyama, A., Havanond, S., Srisawatt, W., Mochida, Y., Fujimoto, K., Ohnishi, T., Ishihara, S., Miyagi, T., 2000. Top/root biomass ratio of a secondary mangrove (Ceriops tagal (Perr.) C.B. Rob.) forest. For. Ecol. Manag. 139, 127-134. https://doi. org /10.1016/S0378-1127(99)00339-4.

Komiyama, A., Ong, J.E., Poungparn, S., 2008. Allometry, biomass, and productivity of mangrove forests: a review. Aquat. Bot. 89, 128-137. https://doi.org/10.1016/j. aquabot.2007.12.006.

Kristensen, E., Bouillon, S., Dittmar, T., Marchand, C., 2008. Organic carbon dynamics in mangrove ecosystems: a review. Aquat. Bot. Mangrove Ecol. Appl. For. Coastal Zone Manage. 89, 201-219. https://doi.org/10.1016/j.aquabot.2007.12.005.

Lallier-Vergès, E., Marchand, C., Disnar, J.-R., Lottier, N., 2008. Origin and diagenesis of lignin and carbohydrates in mangrove sediments of Guadeloupe (French West Indies): evidence for a two-step evolution of organic deposits. Chem. Geol. 255, 388-398. https://doi.org/10.1016/j.chemgeo.2008.07.009.
Lamb, A.L., Wilson, G.P., Leng, M.J., 2006. A review of coastal palaeoclimate and relative sea-level reconstructions using $\delta 13 \mathrm{C}$ and $\mathrm{C} / \mathrm{N}$ ratios in organic material. Earth Sci. Rev. 75, 29-57. https://doi.org/10.1016/j.earscirev.2005.10.003.

Lecolle, J.F., Cabioch, G., 1988. La limite Holocene-Pleistocene dans le recif frangean Ricaudy (Nouvelle-Caledonie). Geochronologie, facies et diagenese. Implications eustatiques et neotectoniques. Mar. Geol. 81, 241-260. https://doi.org/10.1016/ 0025-3227(88)90030-8.

Leopold, A., Marchand, C., Deborde, J., Chaduteau, C., Allenbach, M., 2013. Influence of mangrove zonation on $\mathrm{CO} 2$ fluxes at the sediment-air interface (New Caledonia). Geoderma 202, 62-70.

Leopold, A., Marchand, C., Renchon, A., Deborde, J., Quiniou, T., Allenbach, M., 2016. Net ecosystem CO 2 exchange in the "Coeur de Voh" mangrove, New Caledonia: effects of water stress on mangrove productivity in a semi-arid climate. Agric. For. Meteorol. 223, 217-232. https://doi.org/10.1016/j.agrformet.2016.04.006.

Li, Z., Saito, Y., Mao, L., Tamura, T., Song, B., Zhang, Y., Lu, A., Sieng, S., Li, J., 2012. Mid-Holocene mangrove succession and its response to sea-level change in the upper Mekong River delta, Cambodia. Quat. Res. 78, 386-399. https://doi.org/10.1016/j. yqres.2012.07.001.

Lunstrum, A., Chen, L., 2014. Soil carbon stocks and accumulation in young mangrove forests. Soil Biol. Biochem. 75, 223-232. https://doi.org/10.1016/j.soilbio.2014.04. 008.

Marchand, C., 2017. Soil carbon stocks and burial rates along a mangrove forest chronosequence (French Guiana). For. Ecol. Manag. 384, 92-99. https://doi.org/10.1016/ j.foreco.2016.10.030.

Marchand, Cyril, Baltzer, F., Lallier-Vergès, Elisabeth, Albéric, Patrick, 2004. Pore-water chemistry in mangrove sediments: relationship with species composition and developmental stages (French Guiana). Mar. Geol. 208. Elsevier, pp. 361-381. https://doi. org/10.1016/j.margeo.2004.04.015. pp.2-4.

Marchand, C., Dumas, P., Virly, S., Duke, N., 2006. Mangrove Biodiversity in New Caledonia. Typologies et Biodiversité des mangroves de Nouvelle-Calédonie. (ZoNéCo program report).

Marchand, C., Allenbach, M., Lallier-Vergès, E., 2011a. Relationships between heavy metals distribution and organic matter cycling in mangrove sediments (Conception Bay, New Caledonia). Geoderma 160, 444-456. https://doi.org/10.1016/j. geoderma.2010.10.015.

Marchand, C., Lallier-Vergès, E., Allenbach, M., 2011b. Redox conditions and heavy metals distribution in mangrove forests receiving effluents from shrimp farms (Teremba Bay, New Caledonia). J. Soils Sediments 11, 529-541. https://doi.org/10. 1007/s11368-010-0330-3.

Marchand, C., Fernandez, J.-M., Moreton, B., Landi, L., Lallier-Vergès, E., Baltzer, F., 2012. The partitioning of transitional metals ( $\mathrm{Fe}, \mathrm{Mn}, \mathrm{Ni}, \mathrm{Cr}$ ) in mangrove sediments downstream of a ferralitized ultramafic watershed (New Caledonia). Chem. Geol. 300-301, 70-80. https://doi.org/10.1016/j.chemgeo.2012.01.018.

Matson, E.A., Brinson, M.M., 1990. Stable carbon isotopes and the C:N ratio in the estuaries of the Pamlico and Neuse Rivers. North Carolina. Limnol. Oceanogr. 35, 1290-1300. https://doi.org/10.4319/lo.1990.35.6.1290.

Mcleod, E., Chmura, G.L., Bouillon, S., Salm, R., Björk, M., Duarte, C.M., Lovelock, C.E., Schlesinger, W.H., Silliman, B.R., 2011. A blueprint for blue carbon: toward an improved understanding of the role of vegetated coastal habitats in sequestering $\mathrm{CO}_{2}$. Front. Ecol. Environ. 9, 552-560. https://doi.org/10.1890/110004.

Meyers, P.A., Lallier-Vergès, E., 1999. Lacustrine sedimentary organic matter records of Late Quaternary paleoclimates. J. Paleolimnol. 21, 345-372.

Mitrovica, J.X., Peltier, W.R., 1991. On postglacial geoid subsidence over the equatorial oceans. J. Geophys. Res. 96, 20053-20071. https://doi.org/10.1029/91JB01284.

Mizanur Rahman, M., Nabiul Islam Khan, M., Fazlul Hoque, A.K., Ahmed, I., 2015. Carbon stock in the Sundarbans mangrove forest: spatial variations in vegetation types and salinity zones. Wetl. Ecol. Manag. 23, 269-283. https://doi.org/10.1007/ s11273-014-9379-x.

Monacci, N.M., Meier-Grünhagen, U., Finney, B.P., Behling, H., Wooller, M.J., 2009. Mangrove ecosystem changes during the Holocene at Spanish Lookout Cay, Belize. Palaeogeogr. Palaeoclimatol. Palaeoecol. 280, 37-46. https://doi.org/10.1016/j. palaeo. 2009.05.013.

Monacci, N.M., Meier-Grünhagen, U., Finney, B.P., Behling, H., Wooller, M.J., 2011. Paleoecology of mangroves along the Sibun River, Belize. Quat. Res. 76, 220-228.

Murdiyarso, D., Purbopuspito, J., Kauffman, J.B., Warren, M.W., Sasmito, S.D., Donato, D.C., Manuri, S., Krisnawati, H., Taberima, S., Kurnianto, S., 2015. The potential of Indonesian mangrove forests for global climate change mitigation. Nat. Clim. Chang. 5, 1089-1092. https://doi.org/10.1038/nclimate2734.

Nunn, P.D., Carson, M.T., 2015. Sea-level fall implicated in profound societal change about 2570 cal yr bp $(620$ bc) in western Pacific island groups. Geo: Geogr. Environ. 2. https://doi.org/10.1002/geo2.3.

Ong, J.E., Gong, W.K., Wong, C.H., 2004. Allometry and partitioning of the mangrove, Rhizophora apiculata. For. Ecol. Manag. 188, 395-408. https://doi.org/10.1016/j foreco.2003.08.002.

Parkinson, R.W., DeLaune, R.D., White, J.R., 1994. Holocene sea-level rise and the fate of mangrove forests within the wider Caribbean region. J. Coast. Res. 1077-1086.

Prasad, M.B.K., Kumar, A., Ramanathan, A.L., Datta, D.K., 2017. Sources and dynamics of sedimentary organic matter in Sundarban mangrove estuary from Indo-Gangetic delta. Ecol. Process. 6. https://doi.org/10.1186/s13717-017-0076-6.

Punwong, P., Marchant, R., Selby, K., 2013. Holocene mangrove dynamics and environmental change in the Rufiji Delta, Tanzania. Veg. Hist. Archaeobotany 22, 381-396. https://doi.org/10.1007/s00334-012-0383-x.

R Development Core Team, Vienna, 2008. R: A language and environment for statistical computing. In: R Foundation for Statistical Computing. Vienna, Austria.

Sanders, C.J., Smoak, J.M., Naidu, A.S., Araripe, D.R., Sanders, L.M., Patchineelam, S.R., 2010. Mangrove forest sedimentation and its reference to sea level rise, Cananeia, 
Brazil. Environ. Earth Sci. 60, 1291-1301. https://doi.org/10.1007/s12665-0090269-0.

Sanders, C.J., Maher, D.T., Tait, D.R., Williams, D., Holloway, C., Sippo, J.Z., Santos, I.R., 2016. Are global mangrove carbon stocks driven by rainfall? Mangrove carbon stocks. J. Geophys. Res. Biogeosci. 121, 2600-2609. https://doi.org/10.1002/ 2016JG003510.

Tamooh, F., Huxham, M., Karachi, M., Mencuccini, M., Kairo, J.G., Kirui, B., 2008. Belowground root yield and distribution in natural and replanted mangrove forests at Gazi bay, Kenya. For. Ecol. Manag. 256, 1290-1297. https://doi.org/10.1016/j.foreco. 2008.06.026.

Thornton, S.F., McManus, J., 1994. Application of organic carbon and nitrogen stable isotope and $\mathrm{C} / \mathrm{N}$ ratios as source indicators of organic matter provenance in estuarine systems: evidence from the Tay Estuary, Scotland. Estuar. Coast. Shelf Sci. 38, 219-233. https://doi.org/10.1006/ecss.1994.1015.

Twilley, R.R., Chen, R.H., Hargis, T., 1992. Carbon sinks in mangroves and their implications to carbon budget of tropical coastal ecosystems. In: Natural Sinks of CO2. Springer, pp. 265-288.

Voß, M., Struck, U., 1997. Stable nitrogen and carbon isotopes as indicator of eutrophication of the Oder river (Baltic sea). Mar. Chem. 59, 35-49.

Wang, G., Guan, D., Peart, M.R., Chen, Y., Peng, Y., 2013. Ecosystem carbon stocks of mangrove forest in Yingluo Bay, Guangdong Province of South China. For. Ecol.
Manag. 310, 539-546. https://doi.org/10.1016/j.foreco.2013.08.045.

Wirrmann, D., Sémah, A.-M., Debenay, J.-P., Chacornac-Rault, M., 2011. Mid- to late Holocene environmental and climatic changes in New Caledonia, southwest tropical Pacific, inferred from the littoral plain Gouaro-Déva. Quat. Res. 76, 229-242. https:// doi.org/10.1016/j.yqres.2011.04.007.

Woodroffe, C.D., 1981. Mangrove swamp stratigraphy and Holocene transgression, Grand Cayman Island, West Indies. Mar. Geol. 41, 271-294.

Woodroffe, S.A., Long, A.J., Punwong, P., Selby, K., Bryant, C.L., Marchant, R., 2015. Radiocarbon dating of mangrove sediments to constrain Holocene relative sea-level change on Zanzibar in the southwest Indian Ocean. The Holocene 25, 820-831.

Woodroffe, C.D., Rogers, K., McKee, K.L., Lovelock, C.E., Mendelssohn, I.A., Saintilan, N., 2016. Mangrove sedimentation and response to relative sea-level rise. Annu. Rev. Mar. Sci. 8, 243-266. https://doi.org/10.1146/annurev-marine-122414-034025.

Yamano, H., Cabioch, G., Chevillon, C., Join, J.-L., 2014. Late Holocene sea-level change and reef-island evolution in New Caledonia. Geomorphology 222, 39-45. https://doi. org/10.1016/j.geomorph.2014.03.002.

Yulianto, E., Sukapti, W., Rahardjo, A., Noeradi, D., Siregar, D., Suparan, P., Hirakawa, K., 2004. Mangrove shoreline responses to Holocene environmental change, Makassar Strait, Indonesia. Rev. Palaeobot. Palynol. 131, 251-268. https://doi.org/ 10.1016/j.revpalbo.2004.03.009. 